\title{
MYCOPLASMA SYNOVIAE INFECTION ON NEWCASTLE DISEASE VACCINATION OF CHICKENS
}

\author{
Rita de Cássia Figueira Silva ${ }^{1 *}$; Elmiro Rosendo do Nascimento²; Virgínia Léo de Almeida Pereira²; \\ Maria Lúcia Barreto ${ }^{3}$; Maria da Graça Fichel do Nascimento ${ }^{4}$
}

${ }^{1}$ Laboratório de Biologia Animal, Empresa de Pesquisa Agropecuária do Estado do Rio de Janeiro, Niterói, RJ, Brasil; ${ }^{2}$ Departamento de Saúde Coletiva Veterinária e Saúde Pública, Faculdade de Veterinária, Universidade Federal Fluminense, Niterói, RJ, Brasil; ${ }^{3}$ Núcleo de Animais de Laboratório, Universidade Federal Fluminense, Niterói, RJ, Brasil; ${ }^{4}$ Agroindústria de Alimentos, Empresa Brasileira de Pesquisa Agropecuária, Rio de Janeiro, RJ, Brasil.

Submitted: March 20, 2007; Returned to authors for corrections: November 05, 2007; Approved: April 29, 2008.

\begin{abstract}
Newcastle disease is characterized by respiratory manifestations in association with nervous and/or digestive symptoms. Its prevention is done by vaccination with live attenuated (lentogenic strains) and/or killed vaccines. The lentogenic strains can lead to strong post-vaccination reaction, principally due to the presence of other pathogenic agents. Among them, Mycoplasma synoviae is worldwide important, mainly in Brazil. The dissemination of this agent in poultry flocks has been achieved due to difficulties in diagnosis and disease reproduction, virulence variations among different M.synoviae strains, and attribution of typical M.synoviae disease manifestation to other disease agents. This experimental study in SPF chicks (Gallus gallus), previously infected by M.synoviae and thereafter vaccinated against Newcastle disease, was done with the objective of evaluating M.synoviae pathogenicity through assessment of post-vaccinal respiratory reactions and serologic responses to Newcastle disease virus vaccine in the absence of environmental factors. A total of 86 three days old chicks were used, being 57 infected by eye and nostril drop, with chicken activated M. synoviae strain WVU 1853. Seven days later, 21 mycoplasma infected birds plus 29 not mycoplasma infected ones were vaccinated against Newcastle disease. As results, the not infected and vaccinated birds yielded, significantly, higher and longer lasting serologic responses to Newcastle disease vaccine virus than those infected and vaccinated. Similarly, the infected and vaccinated birds yielded lower serologic reactions to M.synoviae than those only mycoplasma infected. No post-vaccinal respiratory reaction was observed in the vaccinated birds.
\end{abstract}

Key-words: vaccine, serology, Mycoplasma, Newcastle disease.

\section{INTRODUCTION}

In the last 30 years, the Brazilian poultry production is an important sector of the agribusiness and has reached high productivity levels. Nowadays, the most strict foreign import markets acknowledge the standard of quality and sanitary safety of the Brazilian broiler meat (1). To ensure the supply of poultry products and by-products with reliable sanitary quality, the Brazilian Ministry of Agriculture, Livestock and Food Supply MAPA ("Ministério da Agricultura, Pecuária e Abastecimento"), through the National Poultry Health Program - PNSA ("Programa Nacional de Sanidade Avícola"), conducts the control and/or eradication of Avian Mycoplasmosis and Newcastle Disease (ND), among other diseases (6).

Worldwide, respiratory diseases remain one of the major health problems to the Poultry Industry and among them, mycoplasmosis and viral infections, such as ND are associated with high economic losses. Moreover, may act as sanitary barrier to the trading of avian products and by-products, as they are listed as notifiable diseases by the Animal Health World Organization - OIE (27).

*Corresponding Author. Mailing address: PESAGRO - RIO, Laboratório de Biologia Animal, Al. São Boaventura 770, CEP 24120-191 Niterói - RJ. Tel.: (+5521) 36039200 / R.268. E-mail: rcassia@pesagro.rj.gov.br 
ND is one of the most severe avian diseases, caused by avian paramyxovirus type I serotype of the genus Avulavirus belonging to the subfamily Paramyxovirinae, family Paramyxoviridae. Several avian species are susceptible to ND virus infection, being chicken, turkey and pheasant the most susceptible ones (28). Depending on the virulence of the ND strain, digestive and/or nervous manifestations may be present in affected birds. In worldwide conception, ND by low virulent strains is enzootic in Asia, Africa, Central America and part of South America, representing a permanent hazard to the Poultry Industry. ND virulent strains are associated to severe economic losses due to high morbidity and mortality, drop in egg laying and lesions of the upper respiratory and digestive tracts $(3,12,30)$.

In Brazil, after 1995 there has been no report of ND outbreaks in commercial poultry farms. In 1997, ND by virulent strain was reported in the State of São Paulo from imported ostriches, followed by one report in 1999 in the State of Paraná from imported exotic birds (30). The most recent outbreaks occurred in backyard chickens and were notified in Rio de Janeiro (RJ) and Goiás (GO), in 2000 and 2001 respectively, followed by outbreaks in 2006 in Rio Grande do Sul (RS), Amazonas (AM) and Mato Grosso (MT). These outbreaks in backyard chickens from RJ, GO, RS, AM and MT were regarded by OIE as not important for the international trading of avian products and by-products, hence they did not affect the Brazilian exports (26). However, OIE member countries, such as Brazil, should notify the occurrence of any ND case in their territories $(6,9,27)$.

Prevention of ND is achieved by the use of strict hygiene and biosafety control measures $(3,7)$ and regular vaccination procedures $(3,9,30)$. Despite the fact that the Brazilian Broiler production and export regions are considered free from ND (10) and located far from regions where ND is endemic, vaccination is stimulated, in order to avoid chicken flocks susceptible to any kind of ND virus (12).

The use of live attenuated and/or killed ND vaccines depends on the type of poultry and the local risk. The live vaccines produced from lentogenic (low virulence) strains of ND virus have been used with great success (2), but such strains, especially La Sota and Hitchner B1, may elicit clinical disease, characterized by respiratory signs, when administered to fowls infected with other respiratory agents (4). Beard and Brugh (5) suggested that these post vaccination reactions can be reduced when the choice of vaccine strain as well as the route of vaccination are selected based on the presence or absence of Mycoplasma gallisepticum (MG) and/or Mycoplasma synoviae (MS) in poultry flocks.

Mycoplasmas are microorganisms of the class Mollicutes, known to have interactions with other infectious agents and environmental factors, which may increase the severity of mycoplasmosis (20). MG and MS may cause Chronic Respiratory Disease (CRD), an upper respiratory disease primarily seen in chickens; infectious sinusitis in turkeys caused by MG; infectious synovitis caused by MS, and airsacculitis caused by MG, MS and Mycoplasma meleagridis (MM). However, chronic and asymptomatic infections are the most common and of a major concern, due to the losses they cause (19). Some mycoplasma species may adversely affect egg production, egg quality and hatching, in addition to increase in mortality and reduction in feed efficiency and weight gain. They may also cause carcass condemnation, mainly due to airsacculitis $(13,25)$. The infection caused by MS is often characterized by the absence of clinical signs or only mild respiratory disease, although in the 1970 s and 80 s, the most common form of infection was synovitis and arthritis (33). Synergism has been reported between MS and other infections agents. Dissemination and change in behavior have been reported to occur, in the presence of infections agents, such as Infectious Bronchitis virus, ND virus, Influenza A virus, Escherichia coli, MG and MM. Their interactions have been described as synergistic pathogenic effect $(13,21,33)$.

According to the most recent Brazilian regulation, breeders should be free of MG, MS and /or MM, regardlen the specie. Tertiary breeder flocks, which produce broiler and commercial laying chicks, are not required to be MS-free (8). Some poultry producers and veterinarians believe that MS is harmless to the domestic fowl. However this belief might be due to difficulties in reproducing MS disease in chickens, failures in diagnosis and prevalence, and variation of virulence among different MS strains and attribution of typical MS disease manifestation (21). Consequently, MS control and eradication have been neglected, allowing dissemination in poultry flocks over the world.

This experimental study was carried out in specific pathogen free (SPF) chicks, previously infected by MS and thereafter vaccinated against $\mathrm{ND}$, aiming to evaluate the MS pathogenicity through assessment of post-vaccinal respiratory reactions and serologic responses to ND vaccine in the absence of environmental factors.

\section{MATERIALS AND METHODS}

\section{MS activation}

Prior to the onset of this study, MS WVU 1853 type strain (ATCC 25204) was propagated three times in Frey's medium (14) and then inoculated into 12 days-old SPF chickens. These birds were inoculated intratracheally with $0.1 \mathrm{~mL}$ of MS broth culture, containing $1 \times 10^{9}$ color changing units $(\mathrm{CCU}) / \mathrm{mL}(16)$. Seven days later, MS was recovered from tracheal swabs using Frey's broth and agar plate media. The MS type strain was cloned and its identity confirmed by Indirect Immunoperoxidase test (17), before its use in the experimental infection step.

\section{Experimental design}

A total of 96 one day-old SPF White Leghorn chicks (BIOVET S/A, Vargem Grande Paulista, SP, Brazil) were used as 
Table 1. Experimental Design and procedures.

\begin{tabular}{|c|c|c|c|c|}
\hline Ages (days) & Procedures & Experimental Groups & Sampling & Diagnostic Approach \\
\hline 3 & MS infection & $\mathrm{Nd}$ & $\mathrm{Nd}$ & - \\
\hline \multirow{2}{*}{10} & bleeding necropsy & $\mathrm{Nd}$ & $\begin{array}{l}\text { serum lung } \\
\text { trachea }\end{array}$ & $\begin{array}{l}\text { serology MS/MG and MS } \\
\text { molecular detection (PCR) (7 dpi) }\end{array}$ \\
\hline & Groups establishment & MSI; MSI-NDVC; NDVC & $\mathrm{Nd}$ & - \\
\hline \multirow{2}{*}{17} & bleeding & MSI; MSI-NDVC; NDVC & serum & serology MS/MG (14 dpi) and NDV (7 dpv) \\
\hline & necropsy & MSI; MSI-NDVC & lung trachea & MS molecular detection (PCR) (14 dpi) \\
\hline \multirow{2}{*}{24} & bleeding & MSI; MSI-NDVC; NDVC & serum & serology MS/MG (21 dpi) and NDV (14 dpv) \\
\hline & necropsy & MSI; MSI-NDVC & lung trachea & MS molecular detection (PCR) (21 dpi) \\
\hline 38 & necropsy & MSI; MSI-NDVC & lung trachea & MS molecular detection (PCR) (35 dpi) \\
\hline \multirow{2}{*}{45} & bleeding & MSI; MSI-NDVC; NDVC & serum & serology MS/MG (42dpi) and NDV (35 dpv) \\
\hline & necropsy & MSI; MSI-NDVC & lung trachea & MS molecular detection (PCR) (42 dpi) \\
\hline
\end{tabular}

MS - Mycoplasma synoviae; MG - Mycoplasma gallisepticum; NDV - Newcastle Disease Virus; dpi - days post-MS infection; dpv - days post-ND vaccination; Nd - not done; MSI - MS infected birds group; MSI-NDVC - MS infected and ND vaccinated birds group; NDVC - ND vaccinated birds group.

described in the Table 1. Ten randomly selected chicks, with one day of age, were withdrawn, bled and confirmed negative for MS and MG by serum plate agglutination (SPA) with commercial antigen (BIOVET S/A, Vargem Grande Paulista, SP, Brazil). SPA reaction was completed after homogenization of antigen and serum and rotational shaking movements of these reagents on glass plat for up to two minutes. The formation of agglutination clots indicated a positive reaction while the appearance of a transparent homogenate was considered a negative reaction (19). The chicks were further confirmed negative for ND virus by hemagglutination-inhibition (HI) test, according to standard procedures using microtiter plates and four hemagglutinating units of antigen (7).

At three days of age 57 chicks, out of those 86 left, were infected with the chicken activated MS type strain by the eyedrop and intranasal (IN) routes with $0.1 \mathrm{~mL}$ of MS broth culture in the $2^{\text {nd }}$ passage $\left(1 \times 10^{10} \mathrm{CCU} / \mathrm{mL}\right)$, being $0.025 \mathrm{~mL}$ per eye and nostril. Twenty-nine chicks, not MS infected, were separated.

Seven days later, when they were 10 days of age, those 29 birds not MS infected plus 21, MS infected, were ND vaccinated by $\mathrm{IN}$ route with $0.03 \mathrm{~mL}$ per bird, according to the manufacture's instructions of the ND virus live La Sota vaccine (BIOVET S/A, Vargem Grande Paulista, SP, Brazil).
On the ND vaccination day, three experimental groups emerged as follows: (a) MSI, 21 birds infected with MS; (b) MSI-NDVC, 21 birds MS infected and ND vaccinated; (c) NDVC 29 birds, not MS infected, but ND vaccinated.

All experimental groups were housed in isolated rooms belonging to the Experimental Animal Unit of the Animal Biology Laboratory / PESAGRO-RIO. Recommendations on animal care in experimental trials were followed, as well as the ethical principles for experimental animal studies (11).

\section{Serology and MS detection}

All chicks were monitored daily for the presence of clinical signs and death at three to 45 days of age. At weekly intervals, 10 to 45 days of age, eight chicks of the MSI, MSI-NDVC and NDVC groups were randomly selected for monitoring purpose. The selection at 10 days of age was done before ND vaccination. The chicks were bled and three from each MSI and MSI-NDVC groups were necropsied being the lung and tracheal samples used for MS molecular detection by polymerase chain reaction (PCR). Sample sera obtained and organ fragments collected were stored in flasks under freezing at $-20^{\circ} \mathrm{C}$ until use.

Sample processing for PCR was accomplished with $1 \mathrm{~mL}$ of defrosted homogenate, followed by microfuge centrifugation $\left(15000 \mathrm{xg} / 20 \mathrm{~min} . \mathrm{a} 10^{\circ} \mathrm{C}\right)$, being the supernatant discarded and 
the sediment, about $40 \mu \mathrm{L}$, used for DNA extraction by the Phenol/chloroform procedure, according to Sambrook et al. (32). DNA amplification was carried out in a thermocycler PTC-100 (Peltier Effect Cycling, ML Research, Inc). It were used four cycling procedures: heating at $94^{\circ} \mathrm{C} / 3$ minutes (DNA strand separation), followed by 39 cycles of $94^{\circ} \mathrm{C} / 1$ minute (denaturation), $52^{\circ} \mathrm{C} / 1$ minute (annealing) and $72^{\circ} \mathrm{C} / 2$ minutes (extension), followed by further extension of $72^{\circ} \mathrm{C} / 5$ minutes and cooling at $4^{\circ} \mathrm{C} / 10 \mathrm{~min}$. Each eppendorf reaction tube received: $52 \mu \mathrm{L}$ de Milli-Qwater, Gibco BRL; $10 \mu \mathrm{L}$ of PCR $10 \mathrm{X}$ buffer Gibco BRL; $5 \mu \mathrm{L}$ of $\mathrm{MgCl}_{2} ; 5 \mu \mathrm{L}$ of DNTP mix $(0,25 \mathrm{mM}$ from each DNTP), $4 \mu \mathrm{L}$ (100 pmol) of primer MSL - (5'GAGA AGCAAAATAGTGATATCA 3') and the same amount of primer MSR - (5'CAGTCGTCTCCGAAGTTAACAA3') (Biosynthesis - lot C228-26); $20 \mu \mathrm{L}$ of sample DNA in TRIS -EDTA(TE) solution and $2 \mu \mathrm{L}$ of Taq Polymerase(CENTBIOS - lot 1309, RS, Brazil), totalizing $100 \mu \mathrm{L}$ which were covered by two drops of mineral oil (22). The PCR positive control was achieved with MS WVU 1853 broth culture, while the negative one, was accessed with MG type strain (ATCC 19610) under the same conditions. Amplicons were visualized after agarose gel electrophoresis and staining with ethidium bromide under ultraviolet transilumination.

All serum samples were inactived by heating at $56^{\circ} \mathrm{C} / 30$ minutes, to destroy non-specific inhibitors, and tested for MS and MG by SPA. In case of undiluted serum with positive reaction, further dilutions from 1:5 up to 1:160 were made, being a titer of 1:10 or above considered a positive result (19). The proportions of seropositive birds in each group by collection day were obtained and analyzed by chi-square test with 5\% significance level (24). For the immune response to
ND vaccine virus, the HI test was employed and analyzed by geometric mean titer (GMT) $\log _{2}$ where the titer equal to 4.0 or above is indicative of protection $(2,30)$. Thereafter, the obtained data were analyzed by Student's t-test with 5\% significance level (24).

\section{RESULTS}

The MS strain was recovered by PCR from lungs and tracheal samples of all MS infected chicks. The positive control yielded the expected 250 base pairs amplicon while the negative control yielded no amplification band.

All MS infected chicks exhibited weakness and depression from four to five days post-MS infection (dpi), when $21.0 \%$ (12/ 57) of them died. However, none of these birds exhibited respiratory or arthritic signs. Following ND vaccination, respiratory manifestations were not seen in any of the vaccinated chicks. Three vaccinated birds died due to unrelated causes, being one from the MSI-NDVC group at two days post vaccination (dpv), and two from the NDVC group, respectively, at four and five dpv.

Serum samples collected at 10 days of age, before establishment of the experimental groups, seroconverted to MS by SPA test at rates of $50.0 \%(4 / 8)$ and $20.0 \%$ (2/8), respectively, for undiluted and diluted sera (Table 2). All serum samples were negative to MG antibodies. Serum samples collected from chicks of the NDVC group from 17 to 45 days of age were negative by SPA for MS and MG antibodies, as shown in Table 2. In the same period, the SPA positivity rates in undiluted and diluted sera to MS for chicks of the MSI-NDVC group were significantly lower $(\mathrm{p}<0.05)$ than those from the MSI group by chi-square

Table 2. Percentages of M. synoviae (MS) seropositivity by SPA in undiluted (UD) and diluted (D) sera and GMT/HI (log 2 ) to Newcastle Disease (ND) vaccine virus in MS infected (MSI), MS infected and ND vaccinated (MSI-NDVC) and not MS infected, but ND vaccinated (NDVC) birds groups.

\begin{tabular}{|c|c|c|c|c|c|c|c|c|c|c|c|}
\hline \multirow{4}{*}{ Days of age } & \multirow{4}{*}{ dpi } & \multirow{4}{*}{$\mathrm{dpv}$} & \multicolumn{9}{|c|}{ Experimental Groups } \\
\hline & & & \multicolumn{3}{|c|}{ MSI } & \multicolumn{3}{|c|}{ MSI-NDVC } & \multicolumn{3}{|c|}{ NDVC } \\
\hline & & & \multicolumn{2}{|c|}{$\operatorname{SPA}(\%)^{*}$} & \multirow[t]{2}{*}{ HI(GMT) } & \multicolumn{2}{|c|}{ SPA $(\%)$} & \multirow[t]{2}{*}{ HI ** (GMT) } & \multicolumn{2}{|c|}{ SPA $(\%)$} & \multirow[t]{2}{*}{ HI(GMT) } \\
\hline & & & UD & D & & UD & D & & UD & D & \\
\hline 10 & 7 & - & $50.0^{\mathrm{a}}$ & $20.0^{\mathrm{a}}$ & 0 & $\mathrm{Nd}$ & $\mathrm{Nd}$ & $\mathrm{Nd}$ & $\mathrm{Nd}$ & $\mathrm{Nd}$ & $\mathrm{Nd}$ \\
\hline 17 & 14 & 7 & $90.0^{\mathrm{a}}$ & $60.0^{\mathrm{a}}$ & 0 & $66.7^{b}$ & $22.3^{b}$ & 0 & 0 & $\mathrm{Nd}$ & 0 \\
\hline 24 & 21 & 14 & $55.6^{\mathrm{a}}$ & $56.6^{\mathrm{a}}$ & 0 & $22.3^{\mathrm{b}}$ & $11.2^{\mathrm{b}}$ & $4.5^{\mathrm{a}}$ & 0 & $\mathrm{Nd}$ & $5.0^{\mathrm{b}}$ \\
\hline 31 & 28 & 21 & $50.0^{\mathrm{a}}$ & $50.0^{\mathrm{a}}$ & 0 & $20.0^{\mathrm{b}}$ & $10.0^{\mathrm{b}}$ & $3.2^{\mathrm{a}}$ & 0 & $\mathrm{Nd}$ & $5.0^{\mathrm{b}}$ \\
\hline 38 & 35 & 28 & $37.5^{\mathrm{a}}$ & $25.0^{\mathrm{a}}$ & 0 & $22.3^{\mathrm{b}}$ & $0^{\mathrm{b}}$ & $0^{\mathrm{a}}$ & 0 & $\mathrm{Nd}$ & $4.8^{\mathrm{b}}$ \\
\hline 45 & 42 & 35 & $20.0^{\mathrm{a}}$ & $0^{\mathrm{a}}$ & 0 & $16.7^{\mathrm{b}}$ & $0^{\mathrm{b}}$ & $0^{\mathrm{a}}$ & 0 & $\mathrm{Nd}$ & $3.2^{\mathrm{b}}$ \\
\hline
\end{tabular}

dpi - days post-MS infection; dpv - days post-ND vaccination; GMT - geometric mean titer; Nd - not done; *SPA (\%) - row numbers followed by different letters, differ significantly $(\mathrm{p}<0.05)$ by chi-square test; **HI $(\mathrm{GMT})$ - row numbers followed by different letters, differ significantly $(p<0.05)$ by Student's t-test. 
test as shown in Table 2. By HI test to ND vaccine virus, serum samples collected at seven and onwards up to $35 \mathrm{dpv}$, from chicks of the MSI group were all negative. GMT/HI titers to ND vaccine virus for chicks from the MSI-NDVC group, in the same period, were significantly lower $(\mathrm{p}<0.05)$ than those from the NDVC group by Student's t-test as shown in Table 2.

\section{DISCUSSION}

In this study, the MS infection with the strain WVU 1853 in SPF three days-old chicks, through the eyedrop routes and IN, was not able to cause respiratory manifestations or arthritis in the birds probably due to genetic difference. Salisch et al. (31) did not see clinical signs and lesions, but obtained high seropositivity rate of $70.0 \%$ by SPA test, in naturally infected adult chickens. Kawakubo et al. (18) inoculated 28 days-old SPF chickens with MS WVU 1853 strain by IN route, and at 14 dpi, they reported swollen tíbio-tarsial joint that came to normal few days later. Lockaby et al. (23) inoculated SPF one day old chicks, via foot pad, with the same MS strain used here and they observed clinical signs and gross arthritic lesions, characteristics of MS disease at 14 and $21 \mathrm{dpi}$, respectively. The detection of the MS strain by PCR in lungs and tracheal fragments of infected chicks was a rapid and specific procedure, as also observed by Lauerman et al. (22) and Salisch et al. (31). Following ND vaccination, no respiratory manifestations were observed in chickens from all experimental groups.

The SPA test to evaluate the immune response to MS infection was chosen because of its known efficacy in comparison with HI test, as mentioned in previous studies by Ghazikhanian et al. (15), Ortiz and Kleven (29) and Ewing et al. (13). The drop in seroconversion to MS in chicks from the MSINDVC group was clearly detected by this test, in disagreement with what was obtained by Lockaby et al. (23), who found all birds from seven to $14 \mathrm{dpi}$, negative to MS, by SPA and HI tests. The possible justification of that was the use of the footpad route for MS infection by this author.

The serological responses of the MSI birds group were stronger than those from the MSI-NDVC group. These results are in agreement with Wyeth (34), who used the same MS strain through spray route in 42 days-old chickens. When the footpad route was used, Wyeth observed joint lesions, strong serologic response, and weak spreading of the used MS strain. Considering that all MS infected chicks got ill, the obtained results are in agreement with Ewing et al. (13), where the HI seropositivity percentage and GMT/HI titers to ND vaccine virus, for chickens exposed to MS high virulent K3344 strain and ND vaccination, were lower than those obtained when the MS K3344 was replaced by a low virulent MS strain.

According to Alexander (2) and Paulillo and Doretto (30), susceptible chickens vaccinated with lentogenic ND La Sota strain are considered protected when the GMT /HI $\left(\log _{2}\right)$ antibodies reach values equal to 4.0 or greater. In the present study, chicks vaccinated with only one dose yielded GMT /HI $\left(\log _{2}\right)$ titer of 5.0, which dropped to 4.8 , from 14 to $28 \mathrm{dpv}$. Those MS infected and ND vaccinated seven days later, reached a maximum of 4.5 , and fell to 0 (zero), in the same period, indicating the need for revaccination, if they were commercial chickens.

In conclusion, this experimental study demonstrated that vaccination against ND in previously MS infected chicks might be compromised due to failure in immune response, confirming MS pathogenicity.

\section{ACKNOWLEDGEMENTS}

To "EMBRAPA" - Brazilian Institution for Agricultural Research and "CNPq" - National Council for Scientific and Technological Development for financial support provided. To BIOVET S/A, Vargem Grande Paulista, SP, Brazil, for providing the SPF chicks, vaccine and antigens used in the present study. Finally, our thanks to Dr. Maria Ângela Orsi and Dr. Luciano Doretto from "LANAGRO - National Livestock Laboratory", Campinas-SP, MAPA - Ministry of Agriculture, Livestock and Food Supply, for their advices and encouragement to this work.

\section{RESUMO}

\section{Infecção por Mycoplasma synoviae na vacinação da doença de Newcastle em galinhas}

A doença de Newcastle é caracterizada por manifestações respiratórias associadas a sintomas nervosos e/ou digestivos. Sua prevenção é feita pela vacinação com vacinas vivas atenuadas (cepas lentogênicas) e/ou inativadas. As cepas lentogênicas podem determinar acentuada reação pós-vacinal, principalmente na presença de outros patógenos. Entre eles, o Mycoplasma synoviae tem importância mundial, principalmente no Brasil. A disseminação deste agente nos planteís avícolas tem sido facilitada, devido a dificuldades de reprodução e diagnóstico da doença em aves, variação de virulência entre as diferentes cepas de M.synoviae e atribuição a outros patógenos de manifestação típica da micoplasmose por M.synoviae. Este estudo experimental em aves (Gallus gallus) SPF, previamente infectadas por M.synoviae e depois vacinadas contra Newcastle, foi realizado com objetivo de avaliar a patogenicidade do M.synoviae pela obtenção da reação respiratória pós-vacinal e a resposta sorológica para o vírus vacinal da doença de Newcastle, na ausência de fatores ambientais. Um total de 86 aves, com três dias de idade foram utilizadas, sendo 57 infectadas via ocular e intranasal, com cepa MS WVU 1853, ativada em galinhas. Sete dias depois, 21 aves infectadas por micoplasma e 29 não infectadas foram vacinadas contra a doença de Newcastle. Como resultados, aves não infectadas e vacinadas produziram resposta sorológica para o vírus vacinal da doença de Newcastle, 
significativamente mais elevada e mais duradora que aquelas infectadas e vacinadas. Igualmente, aves infectadas e vacinadas produziram reações sorológicas para M.synoviae mais baixa, que aquelas apenas infectadas. Não foram observadas reações respiratórias pós-vacinal nas aves vacinadas.

Palavras-chave: vacina, sorologia, micoplasma, doença de Newcastle

\section{REFERENCES}

1. Associação Brasileira de Produtores e Exportadores de Frangos (2006). Consumo brasileiro de carne de frangos. Available at: http:// www.abef.com.br/Estatisticas/MercadoInterno. Accessed 10 October 2006.

2. Alexander, D.J. (1997). Newcastle Disease and other paramyxovirus infections. In: Calnek, B.W., Barnes, H.J., Beard, C.W., McDougald, L.R., Saif, Y.M. (eds). Dis. Poult., Iowa State University Press, Ames, USA, p. 541-569.

3. Alexander, D.J. (2003). Newcastle Disease, Other Avian Paramyxoviruses, and Pneumovirus infections. In: Saif, Y.M., Barnes, H.J., Fadly, A.M., Glisson, J.R., McDougald, L.R., Swayne, D.E. Dis. Poult., Iowa State University Press, Ames, USA, p.63-99. CD-ROOM.

4. Allan, W.H. (1997). The problem of Newcastle Disease. Nature, 34, 124-131.

5. Beard, C.W.; Brugh, M. (1975). Immunity to Newcastle disease. Am J. Vet. Res., 36, 509-512.

6. Brasil. Portaria Ministerial $\mathrm{n}^{\circ} 193$, de 19 de setembro de 1994. Institui o Programa Nacional de Sanidade Avícola do Ministério da Agricultura e Abastecimento (MAA). Diário Oficial República Federativa do Brasil, Brasília / DF.

7. Portaria $\mathrm{n}^{\mathrm{o}} 182$, de 08 de novembro de 1994. Aprova as normas de credenciamento e monitoramento de laboratórios de diagnóstico da Doença de Newcastle do Ministério da Agricultura e Abastecimento (MAA). Programa Nacional de Sanidade Avícola. Brasília / DF.

8. Brasil. Instrução normativa $\mathrm{n}^{\circ} 44$, de 23 de agosto de 2001. Aprova as normas técnicas para o controle e certificação de núcleos e estabelecimento avícola para a Micoplasmose Aviária do Ministério da Agricultura, Pecuária e Abastecimento (MAPA). Diário Oficial República Federativa do Brasil, Brasília / DF.

9. Brasil. Instrução normativa $\mathrm{n}^{\circ} 32$, de 13 de maio de 2002. Aprova as normas técnicas de vigilância para Doença de Newcastle e Influenza Aviária, e de controle e erradicação da Doença de Newcastle do Ministério da Agricultura, Pecuária e Abastecimento (MAPA). Diário Oficial República Federativa do Brasil, Brasília / DF.

10. Brasil. Instrução Normativa $n^{0} 17$, de 07 de abril de 2006. Aprova no âmbito do PNSA o Plano Nacional de Prevenção da Influenza Aviária e de controle e Prevenção da Doença de Newcastle do Ministério da Agricultura e Abastecimento (MAA). Programa Nacional de Sanidade Avícola. Diário Oficial da República Federativa do Brasil, Brasília / DF.

11. Colégio Brasileiro de Experimentação Animal (2000). Princípios éticos na experimentação animal. Clin. Vet., 25, 42.

12. Di Fábio, J. (2006). Doença de Newcastle: Vacinar ou não vacinar. Conferência APINCO 2006 de Ciência e Tecnologia Avícolas, Santos, SP, p. 135-140.

13. Ewing, M.L.; Cookson, K.C.; Phillips, R.A.; Turner, K.R.; Kleven, S.H. (1998). Experimental infection and transmissibility of Mycoplasma synoviae with delayed serologic response in chickens. Avian Dis., 42, 230-238.
14. Frey, M.L.; Hanson R.P.; Anderson D.P. (1968). A medium for the isolation of avian mycoplasma. Am. J. Vet. Res., 29, 2163-2217.

15. Ghazikhanian, G.; Yamamoto, R.; Cordy, D.R. (1973). Response to turkey to experimental infection with Mycoplasma synoviae. Avian Dis., 17, 122-126.

16. Goll Jr, F. (1994). Identification of Mycoplasmas isolated from domestic animals. In: Whitford, H.W., Roembansch, R.F., Lauerman, L.H. (eds). Micoplasmosis in Animals: Laboratory Diagnosis. Iowa State University Press, Ames, USA, p.15-30.

17. Imada, Y.; Uchida, L.; Hashimoto, K. (1987). Rapid identification mycoplasmas by indirect imunoperoxidase test using small square filter paper. J. Clin. Microbiol., 25, 17-21.

18. Kawakubo, Y.; Kume, K.; Yoshioka, M.; Nishiyama, Y. (1980). Histo - and immunological studies on experimental Mycoplasma synoviae infection of the chicken. J. Comp. Pathol., 90, 457-467.

19. Kleven, S.H. (1997). Mycoplasma synoviae infections. In: Calnek, B.W., Barnes, H.J., Beard, C.W., Mcdougald, L.R., Saif, Y.M. (eds). Dis. Poultry. Iowa State University Press, Ames, USA, p. 220-228.

20. Kleven, S.H. (1998). Mycoplasmas in the etiology of multifactorial respiratory disease. Poul. Sc., 77, 1146-1149.

21. Kleven, S.H.; King, D.D.; Anderson, D.P. (1972). Airsacculitis in Broiler from Mycoplasma synoviae: Effect on air-sac lesions of vaccinating with infectious bronchitis and Newcastle virus. Avian Dis., 16, 915-924.

22. Lauerman, L.H.; Hoerr, F.J.; Sharpton, A.R.; Shad, S.M.; Santen, L.V. (1993). Development and application of a Polymerase Chain Reaction Assay for Mycoplasma synoviae. Avian Dis., 37, 829834.

23. Lockaby, S.B.; Hoerr, F.J.; Lauerman, L.H.; Kleven, S.H. (1998) Pathogenicity of Mycoplasma synoviae in broiler chickens. Vet. Path., 35, 178-190.

24. Martin, S.W.; Meek, A.H.; Willeberg, P. (1994). Veterinary Epidemiology: Principles and Methods. Iowa State University Press, Ames, USA, p. 121-148.

25. Nascimento, E.R.; Pereira, V.L.A.; Nascimento, M.G.F.; Barreto, M.L. (2005). Avian mycoplasmosis update. Rev. Bras. Cien. Avic., 7 (1), 1-9.

26. OIE. Animal Health World Organization. Animal Health Situation. Available at: http://www.oie.int/eng/info/en_info. Accessed 30 October 2006.

27. OIE. Animal Health World Organization. Diseases Notifiable to the OIE. Available at: http://www.oie.int/eng/maladies/en classification Accessed 04 November 2006.

28. OIE. Animal Health World Organization. Manual of Diagnostic Tests and Vaccines for Terrestrial Animals Diseases. Available at: http:// www.oie.int/eng/normes/mmanual. Accessed 03 Janeiro 2008.

29. Ortiz, A.; Kleven, S.H. (1992). Serological detection of Mycoplasma synoviae infection in turkeys. Avian Dis., 36, 749-752.

30. Paulillo, A.C.; Doretto, L.J. (2000). Doença de Newcastle. In: Berchieri Júnior, A., Macari, M. (eds). Doenças das Aves. Facta, Campinas, SP, p. 267-281.

31. Salisch, H.; Hinz, K.H.; Graack, H.D.; Ryll, M. (1998). A comparison of commercial PCR-based test culture methods for detection of Mycoplasma gallisepticum and Mycoplasma synoviae in concurrently infected chickens. Avian Path., 27, 142-147.

32. Sambrook, J.; Fritsch, E.F.; Maniatis, T. (1989). Molecular Cloning. Laboratory Manual. Cold Spring Harbor Laboratory Press, New York, USA, 3, p. 3-15.

33. Stipkovits, L.; Kempf, I. (1996). Mycoplasmoses in poultry. Rev. Sci. Tech. Off. Int. Epizoot., 15, 1495-1525.

34. Wyeth, P.J. (1974). Influence of route of infection on response of chickens to Mycoplasma synoviae. Vet. Rec., 95, 208-211. 